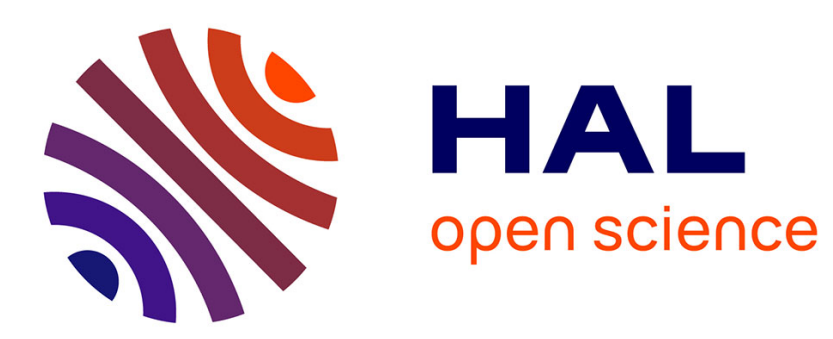

\title{
Impact of hedonic evaluation of technological innovations on revisit intention in a store digitalization context
}

Mbaye Fall Diallo, Isabelle Collin-Lachaud

\section{To cite this version:}

Mbaye Fall Diallo, Isabelle Collin-Lachaud. Impact of hedonic evaluation of technological innovations on revisit intention in a store digitalization context. International Journal of Technology and Human Interaction, 2019, 15 (4), pp.38-53. 10.4018/IJTHI.2019100104 . hal-03156206

\section{HAL Id: hal-03156206 \\ https://hal.science/hal-03156206}

Submitted on 2 Mar 2021

HAL is a multi-disciplinary open access archive for the deposit and dissemination of scientific research documents, whether they are published or not. The documents may come from teaching and research institutions in France or abroad, or from public or private research centers.
L'archive ouverte pluridisciplinaire HAL, est destinée au dépôt et à la diffusion de documents scientifiques de niveau recherche, publiés ou non, émanant des établissements d'enseignement et de recherche français ou étrangers, des laboratoires publics ou privés. 


\title{
Impact of Hedonic Evaluation of
}

\section{Technological Innovations on Revisit}

\section{Intention in a Store Digitalization}

\section{Context}

Pour le citer : DIALLO M.F. et COLLIN-LACHAUD I. (2018) Impact of hedonic evaluation of technological innovations on revisit intention in a store digitalization context, International Journal of Technology and Human Interaction, 15(4): 16p.

\begin{abstract}
This research investigates how hedonic evaluation of technological innovation affects directly store revisit intention and indirectly through the mediation of customer satisfaction and shopping experience. The introduction of new technologies in super-and hypermarkets was studied using a quantitative survey undertaken with 257 real customers. Respondents assessed four innovative tools (automatic check-out, Internet kiosk, Smartphone and self-scanning). Structural equation modeling results show that customer hedonic evaluation of technological innovation affects positively store revisit intention. However, while technology pleasantness influences it significantly technology interactivity does not. Furthermore, we establish significant mediation effects of customer overall satisfaction and shopping experience on the relationship investigated. FIMIX-PLS segmentation
\end{abstract}


identifies two specific groups (low and high hedonic technology seekers). This research stresses retail companies to focus on hedonic aspects of innovative technologies offered in the context of store digitalization and to invest in personnel and accompanying measures that enable a smooth use of technological innovations.

Keywords: Hedonic Evaluation, Technological Innovation, New Technologies, Technology-Human Interaction, Shopping Experience, Satisfaction, Store Revisit Intention, Pleasantness, Interactivity, Mediation Effects, Segmentation. 


\section{INTRODUCTION}

Like many industries (Vasudeva \& Singh 2017), the retail industry is now experiencing various evolutions due to new technologies (Internet, smartphones, ...) (Grewal, Roggeveen \& Nordfält, 2017; Inman \& Nikolova, 2017) that are altering the relationships between retailers and their customers (Pantano \& Viassone, 2014). These increasing uses of technological innovations can enhance consumers' experience (Oh, Teo \& Sambamurthi, 2012; Papagiannidis, Pantano, See-To \& Bourlakis, 2017), as well as retailers' competitiveness and business performance (Inman \& Nikolova, 2017). However, many technological innovations also fail (Chiesa \& Frattini, 2011), which is an outcome with significant financial consequences. Furthermore, retailers use new technologies in their various channels (e.g., stores, websites, mobile applications) to offer seamless experiences and make shopping more convenient for consumers in omnichannel retailing ecosystems (Piotrowicz and Cuthbertson, 2014; Verhoef, Kannan \& Inman, 2015).

Prior studies show that cross-channel integration can increase retailers' performance and improve consumer satisfaction (Van Birgelen, De Jong \& De Ruyter, 2006), yet it is not clear how the introduction of technological innovations might create value for consumers (e.g., shopping experience, satisfaction) or retailers (e.g., store loyalty). But the consequences of introducing innovations are critical, because companies invest heavily in innovative technologies (e.g., interactive kiosks, selfscanning, contactless payment), often without clear knowledge of their effects on consumers and thus on the companies' performance (Inman \& Nikolova, 2017).

Most of prior researches investigated the adoption of technological innovations and its cognitive evaluation (Davis, 1989; Renko \& Druzijanic, 2014). However, shopping is not just about obtaining utilitarian value but also pleasure. An enjoyable shopping experience can lead to higher shopper satisfaction and spending (e.g. Donovan, Rossiter, Marcoolyn \& Nesdale, 1994; Papagiannidis et al., 2017). Consequently, the specific aim of this research is to investigate how positive hedonic evaluation of technological innovations affects directly or indirectly customer satisfaction, shopping experience and store revisit intention. We specifically analyze how customer satisfaction and shopping 
experience mediate the relationship between hedonic evaluation of technological innovations and store revisit intention. Understanding factors affecting directly and indirectly revisit intention is critical in an omnichannel context where customer "showrooming" has become a major threat to physical stores.

This research contributes to existing research in three main ways. First, it shows that hedonic evaluation of technology (including both pleasantness and interactivity aspects) has positive and homogeneous effects across the value creation chain, for both consumers (increased satisfaction and better shopping experience) and retailers (higher store revisit intention). Thus, this study complements existing research on the effects of new technologies in retailing (Inman \& Nikolova, 2017;

Papagiannidis et al., 2017). Second, this research brings further insights about the relationships between hedonic evaluation, customer satisfaction and store revisit intention. This paper specifically establishes a significant mediation effect of customer overall satisfaction on the relationship between hedonic evaluation of technological innovations on store revisit intention. Thus, this result enriches the recent study of Inman \& Nikolova (2017) who showed that satisfaction mediates the effect of retail technology on retail patronage intentions. Furthermore, these results highlight differences between pleasantness and interactivity dimensions. Specifically, this research shows that technology affects positively store revisit intention while technology interactivity does not. Both technology pleasantness and interactivity influence indirectly store revisit intention through the mediation of customer satisfaction and shopping experience.

Third, this research establishes the significant mediation effect of customer shopping experience on the relationship between hedonic evaluation of technological innovations on store revisit intention. Identifying such a mediation effect is important because experience has over the past become the key variable differentiating retail companies one from another (Papagiannidis et al., 2013). Furthermore, while store digitalization has become a significant trend in retailing (Papagiannidis et al., 2017), it not yet clear how hedonic evaluation of innovative technologies affects shopping experience, nor is it obvious how the latter affects behavioral intentions in digitalized stores.

In the next sections, the theoretical framework will first be presented and the related hypotheses. Next, the research methodology will be exposed, followed by the results. Finally, some theoretical and 
managerial implications are proposed and discussed, as well as some limitations and suggestions for further research.

\section{THEORETICAL BACKGROUND}

\section{Technological innovations and store digitalization}

This paper focuses on recent innovations that produce store digitalisation, which refers to a physical store offering interactive technologies (interactive terminals, tablets, dedicated apps, ...) that can be used within the store. The variety of technological innovations introduced recently in the retail sector include automated check-out systems, self-scanning, payment without contact (Near Field Communication), intelligent in-store kiosks (Chang, Fu, Fang, \& Cheng, 2016), Quick Response codes, radio frequency identification (RFID), mobile payments, smart touch screen display, etc. (Inman \& Nikolova, 2017). Most of these technologies relate to SSTs, that are "technological interfaces that enable customers to produce a service independent of direct service employee involvement." (Meuter, Ostrom, Roundtree \& Bitner, 2000, p. 50). These technologies appeal to a more active role of consumers in consumption experience (Collin-Lachaud \& Vanheems, 2016). Among this great variety of technologies, we concentrate on in-store kiosks, smartphones, automated check-out and self-scanning as they are some of the most influential new technologies (Piotrowicz \& Cuthbertson, 2014; Renko \& Druzijanic, 2014).

\section{Hedonic evaluation of technological innovations}

Prior studies cite several characteristics that enable new technologies to create value (Renko \& Druzijanic, 2014). Most of prior researches investigated cognitive evaluation of technological innovations such as ease of use, usefulness and adoption likelihood (Technological Adoption Model) or a cognitive approach (Davis, 1989; Inman \& Nikolova, 2017; Renko \& Druzijanic, 2014). However, since Martineau (1958), we know that shopping is not just about obtaining tangible products but also enjoyment and pleasure, and that an enjoyable shopping experience is often reflected in higher shopper satisfaction and spending (e.g. Donovan et al., 1994; Papagiannidis et al., 2017). The seminal 
work of Holbrook and Hirschman (1982) highlighted the hedonic perspective of consumption experience that refers to the fun, fantasies and feelings. Hedonic evaluation results from the fun and pleasure derived rather than task completion (Chang, Chih, Liou \& Yang., 2016) and can lead to flow experience (Ettis, 2017). More specifically, hedonic evaluation of technologies emerges from fun, enjoyment, entertainment and excitement while interacting with the virtual environment, whereas the overall virtual experiences engage consumers and influence their purchasing behavior (S. Chang et al., 2016; Fiore, Kim \& Lee, 2005).

In this research, we investigate hedonic evaluation of technologies (fun, pleasure) by focusing on two main attributes: pleasantness and interactivity. Pleasantness results from "an evaluation of whether a stimulus is likely to result in pleasure or displeasure" (Lanctôt \& Hess, 2007, pp. 207), which then drives customer behavior. Pleasantness represents one dimension of hedonic evaluation which is rather reactive, but nowadays consumers also enjoy to feel free and hence empowered to use any channel or device (Collin-Lachaud \&Vanheems, 2016), so we added a second and more (pro)-active dimension to hedonic evaluation: interactivity. Interactivity is the "extent to which users can participate in modifying the form and content of a mediated environment in real time" (Steuer, 1992, pp. 84). It offers benefits such as facilitated communications, customised information, manipulation abilities, and entertainment to customers (Fiore et al., 2005). Interactivity meets customers' expectations to be active in the experience (Maditinos \& Theodoridis, 2010; Thorseng \& Grisot, 2017).

\section{Hypotheses development and conceptual model}

\section{Direct effect of customer hedonic evaluations of technological innovations}

Technological innovations have positive effects on value creation for both consumers and retailers (Varadarajan et al., 2010). Adding technological innovations in retail stores can create value in three main ways.

Technological innovations increase store revisit intention which corresponds to the likelihood that consumers revisit the store (Inman \& Nikolova, 2017). Typically, store revisit intention refers to a 
loyalty intention towards the store. Prior studies cite a positive link between technological innovations and consumer loyalty behaviors, in both online and offline contexts (O'Cass \& Carlson, 2012; Renko \& Druzijanic, 2014). Technologies' positive performance on important attributes then is a strong determinant of customer behavioral intentions (O'Cass \&Carlson, 2012), such that entertainment influences customers' intention to shop and also their revisit intention (Hausman \& Siekpe, 2009). Favorable perceptions of innovativeness that arise from the interaction between the consumer and the retailer's technologies specifically reduce the likelihood of switching behavior and increase intention to purchase (O'Cass \& Carlson, 2012). Therefore, we make the following hypothesis:

Hypothesis One: A positive hedonic evaluation of technological innovations increases customers' store revisit intention.

\section{Mediation effects of customer satisfaction and shopping experience}

Prior studies allow anticipate the mediation effect of customer overall satisfaction on the relationship between hedonic evaluation of innovative technologies and store revisit intention. First, technological innovations can enhance customer satisfaction, conceptualized for this study as overall satisfaction (Beatson, Coote \& Rudd, 2006), reflecting customers' fulfillment response to a service experience (Spreng, MacKenzie \& Olshavsky, 1996). The relationship between evaluations of attributes, both innovative and not, and overall satisfaction has been well established (Spreng et al., 1996; Weijters, Rangarajan, Falk \& Schillewaert, 2007). Moreover, adoptions of new technologies (e.g., RFID) result from both the positive consequences of adoption, such as reduced shrinkage, and improved customer satisfaction (Jones, Clarke-Hill, Hillier \&Comfort, 2005). When consumers rate the performance of the various innovative technologies positively, they are more likely to be satisfied with the retail experience overall (Beatson et al., 2006).

Second, satisfaction (Oliver, 1993) has long been recognized as one of the significant antecedents of revisit intention. Several studies demonstrated this positive link in the context of online shopping and virtual retail environments (S. Chang et al, 2016; Maditinos \&Theodoridis, 2010; Fiore et al., 2005; Hausman \& Siekpe, 2009; Papagiannidis et al., 2013, 2017; Rose, Clark, Samouel \& Hair, 2012). 
Besides, according to Inman and Nikolova (2017), satisfaction mediates the effect of technology on shopper retail patronage intentions.

Therefore, we anticipate the following hypothesis:

Hypothesis Two: A positive hedonic evaluation of technological innovations increases customer overall satisfaction (H2a), which in turn affects positively store revisit intention (H2b).

From existing studies, we also can expect a significant mediation effect of customer overall shopping experience on the relationship between hedonic evaluation of innovative technologies and store revisit intention.

On the one hand, technological innovations can improve customers' shopping experience which is defined as "the total summary of a customer's interaction with a retail company beginning before the customer walks into the store and ending long after he or she leaves" (Choi, Yang Y, Yang B. \& Cheung, 2015, pp. 10). According to Reynolds and Sandström (2014), the use of digital devices could make the overall shopping experience better. For example, image interactivity technology, which enables the creation and manipulation of product images on a retailer's website, improves both experiential and instrumental value (Fiore et al., 2005). The interactivity of virtual tools can enhance the shopping experience (Kim \& Forsythe, 2008). Smart systems, such as instrumented smartphones, interconnected Internet kiosks, and intelligent systems (e.g., payment without contact), enable retailers to provide better shopping experiences (Demirkan \& Spohrer, 2014).

On the other hand, we can establish a positive influence of customer shopping experience on store revisit intention. Since the seminal work of Holbrook and Hirschman (1982), a lot of researchers investigated the concept of experience in many domains and sectors (culture, tourism, retail, etc.), but very few focused on the relationship between consumer overall experience and behavioral intentions (Hosany \& Witham, 2010; Triantafillidou \& Siomkos, 2014). Nevertheless, several studies showed that experience positively affects consumer behavioral responses such as purchase intentions and revisit intentions in the context of online store (Etis, 2017; Koufaris, 2002; Lin, Fang \& Tu, 2010). 
Based on this discussion, we postulate that:

Hypothesis Three: A positive hedonic evaluation of technological innovations increases customer overall shopping experience (H3a), which in turn affects positively store revisit intention (H3b).

\section{Control variables}

Different variables such as frequency of use and ease of use, but also individual socio-demographic characteristics (age, gender, income and education) are used as control variables as past studies highlighted their role on the variables analyzed (Morris \&Venkatesh, 2000; Venkatesh \& Morris, 2000; Davis, 1989 ; Koufaris, 2002; Lin et al., 2010 ; Venkatesh, Brown, Maruping \& Bala, 2008).

Figure 1 summarizes the relationships investigated.

\section{PLEASE INSERT FIGURE 1}

\section{RESEARCH METHODOLOGY}

\section{Context and data collection}

We conducted a quantitative research, with a questionnaire administered through an online platform (Google docs). Respondents, targeted with a convenience sampling approach, were all real customers but had different experiences with online and offline shopping. They all used technological tools inside stores when shopping. We asked them to assess the technology they used most frequently among four options: Smartphone, Internet kiosk, self-scanning and automatic check-out. This option allowed respondents give relevant assessment of the technologies used most often. The technologies offered for assessment are chosen because they are the main tools used in supermarkets and hypermarkets in France and across Europe (Piotrowicz \& Cuthbertson, 2014; Renko \& Druzijanic, 2014). 
All participants were at least 18 years of age and fully or partially in charge of purchases of food and nonfood products for their household. They indicated the retail chain where they shopped most often, which ensured their familiarity with the retailer. Overall, we obtained 257 completed questionnaires from customers of French click-and mortar retailers. In terms of their sociodemographic profiles, the sample was diverse, though respondents broadly tended to be women (61\%), young ( $18-25$ years $17.5 \%$; $26-34$ years $51 \%$; $35-49$ years $14.8 \%$; and older than 50 years 16.7\%), and well educated (high school level 17.1\%; Bachelor level 28.8\%; Master level or higher $7.8 \%$ ). The monthly household income is well distributed: $\leq € 1000$ (26.8\%), €1001-2000 (20.6\%), $€ 2001-4000$ (19.1\%), and $>€ 4000$ (4.7\%). These figures highlight the good balance in the sample and roughly replicate the population of people who use digital tools in stores in France.

\section{Measurement scales}

To measure consumer hedonic evaluation of technological innovation, we used two main attributes derived from previous research: pleasantness (Lanctôt \& Hess, 2007) and interactivity (Fiore et al., 2005). Respondents rated each attribute of the innovative technology they used during their shopping trips on a scale from $1=$ "strongly disagree" (negative assessment) to 5 = "strongly agree" (positive assessment) (see Appendix 1). Because we are interested in the overall customer satisfaction, customer overall shopping experience and overall store revisit intention, we used single items to measure these constructs. Using single items has several advantages such as avoiding lengthy questionnaires that can mitigate consumer attention and ultimately data quality, avoiding redundancy (Bergkvist \& Rossiter, 2007) and allowing respondents to express their perceptions and preferences clearly in a short time (Nagy, 2002). Furthermore, with single items, reliability (measured for instance by Cronbach alpha) is no longer an issue as the item captures the whole construct domain. Consequently, customers' overall satisfaction (derived from Beatson et al., 2006), shopping experience (derived from Choi et al., 2015), and store revisit intentions (derived from O'Cass \&Carlson, 2012) were measured by unique indicators, on a five-point agreement scale so the assessments be relevant to our effort to assess customers' overall assessments of the constructs. Finally, we included socio-demographic factors (age, gender, income, education), ease of use and 
frequency of use (five-point scale from $1=$ very low to $5=$ very high) as control variables, to account for their effects. Appendix 1 presents the measurement items.

\section{Data analysis approach}

The data analysis was based on partial least squares (PLS) path modeling, which is appropriate for this research PLS is preferable if the researcher is primarily concerned with predicting the dependent variable (Reinartz, Haenlein \& Henseler, 2009). Therefore, PLS is especially suitable for studies aiming to extend existing structural theories (Hair, Black, Babin \&Anderson, 2014), such as our attempt to explore the dependence between hedonic evaluations of technological innovations and store revisit intention, while also assessing multiple mediators (satisfaction and shopping experience). Furthermore, our data is not multi-normal; thus PLS is more appropriate than covariance-based SEM because it does not make distributional assumptions.

\section{FINDINGS}

\section{Outer model assessment}

We assessed the outer models (measurement models) using SmartPLS 3.0 before moving on to the inner model (structural model) test. Table 1 shows the measurement properties of the constructs (all reflective). We used four criteria to assess the convergent validity and internal consistency of the constructs: item loading, communality $\left(\mathrm{R}^{2}\right)$, reliability indicators (Dillon-Goldstein's rho composite reliability, $\rho$ ), and the construct's average variance extracted (AVE). Furthermore, we confirmed the absence of multicollinearity, which can lead to unstable estimates in PLS: the variance inflation factor values are less than 2 , suggesting that multicollinearity is not an issue in the data analyzed.

\section{PLEASE INSERT TABLE 1}

Table 1 shows that the item loadings between an indicator and its posited underlying construct, on average, are greater than .7. The reliability indicators of constructs exceeded the criterion of .7, and the AVE was above the recommended threshold of .5, in support of convergent validity (Fornell \& 
Larcker, 1981). Table 2 reports the test of discriminant validity along with the correlation matrix, means, and standard deviations. The AVE for each construct was greater than the square of the interconstruct correlations. Thus, all constructs fulfilled the requirement for discriminant validity (Fornell \& Larcker, 1981).

\section{PLEASE INSERT TABLE 2}

We checked for potential common method bias (Podsakoff P., MacKenzie, Lee \& Podsakoff N., 2003), using the smallest correlation of the matrix analyzed ( $\left.r_{\text {ease of use } \times \text { shopping experience }}=-.007\right)$ and the marker variable technique (Malhotra, Kim \& Patil, 2006). We determined that the differences between the original and corrected correlations were small and not significant $(\Delta r<.05)$. Thus, common method bias did not influence the parameter estimates of our study.

\section{Test of hypotheses}

We analyze a partial mediation model, in which hedonic evaluations of technological evaluations influence store revisit intention directly and indirectly through customer overall satisfaction and shopping experience. The variance explained $\left(\mathrm{R}^{2}\right)$ in the endogenous latent variables and $p$-values of the regression coefficients (t-test) indicate the explanatory power of the model. Overall, all the hypothesized relationships in the focal research model are significant at $p<.01$ or $p<.05$. The $\mathrm{R}^{2}$ value of the dependent variable (.24) is acceptable for applied studies. In addition, the GoF values are appropriate and suggest good model fit : GoF $=.42$. Finally, the standardized root mean residual (difference between the observed and predicted correlations) is acceptable (.07).

To test the direct effect of hedonic evaluation of technological innovations on store revisit intention, a bootstrapping estimation verifies the statistical significance of each path coefficient. To test the indirect effects, we first compare the focal model with two alternative models; that is, we compare the focal partial mediation model (M1, both direct and mediation) with a direct model (M2, no mediation, only direct effects) and a full mediation model (M3, no direct effect, only mediations). 
The results show that M1's statistical predictive power $\left(R^{2}=.23\right)$ is similar to those of $M 2\left(R^{2}=.23\right)$, but slightly higher than that of M3 $\left(\mathrm{R}^{2}=0.19\right)$. Model 1 is though theoretically more powerful than M2, because it includes both direct and indirect relationships. Then we test the model overall and in each type of technology, uncovering satisfactory model quality. Using the focal model, we also compute the product of the direct effects using bootstrapping, in line with Cheung and Lau (2008). Because SmartPLS does not reveal the significance of specific indirect effects with bootstrap intervals, we use a Monte Carlo method to assess mediation for such effects (MacKinnon, Lockwood \& Williams, 2004). ${ }^{1}$

Figure 2 summarizes the results obtained. The control variables (socio-demographic factors, technology frequency of use and ease of use) are included in the model, but they have no significant effects on it. Thus, our substantive findings are not likely to change depending on these factors. Customers' hedonic evaluations of technological innovations affect directly store revisit intention ( $\beta=$ $.21, p<.05)$, providing support to H1. The analyses show that hedonic evaluations of technological innovations affect positively customer satisfaction $(\beta=.38, p<.01)$, which in turn influences positively store revisit intention $(\beta=.18, p<.05)$. The product of these two coefficients is significant $(\beta=.07, p<.01)$. This result gives support to $\mathrm{H} 2$ (mediation effect of customer satisfaction). Because the direct effect is significant, this is a partial mediation. We also uncover a positive effect of hedonic evaluations of technological innovations on customer shopping experience $(\beta=.44, p<.01)$. The latter influences positively store revisit intention $(\beta=.22, p<.05)$. The product of these two coefficients is significant, underlining a mediation effect of customer shopping experience $(\beta=.10, p$ $<.01)$. Therefore, $\mathrm{H} 3$ is supported.

\footnotetext{
${ }^{1}$ We performed a parametric bootstrapping method using the online tool provided by Selig and Preacher (http://quantpsy.org/).
} 


\section{PLEASE INSERT FIGURE 2}

In order to better understand the results, we analyzed the direct and indirect effects both for pleasantness and interactivity aspects of customer evaluations. Table 3 summarizes the results obtained. We notice that technology pleasantness influences significantly store revisit intention ( $\beta=$ $.20, p<.01)$, whereas technology interactivity has no direct effect on store revisit intention. Besides, all the mediation effects analyzed are significant both for customer overall satisfaction and shopping experience. We observe that overall satisfaction weakly mediates the relationship between pleasantness and store revisit intention $(\beta=.05, p<.05)$ while customer shopping experience mediates more strongly the effect of interactivity on store revisit intention $(\beta=.09, p<.01)$.

\section{PLEASE INSERT TABLE 3}

\section{Additional analyses and further insights}

To assess the robustness of the results and explicate the relationships, in line with Mancha et al. (2014), we used finite mixture segmentation (FIMIX-PLS) to identify potential unobserved heterogeneity ${ }^{2}$. We used the Akaike Information Criterion (AIC), the Bayesian Information Criterion (BIC), and the entropy statistic (EN) to evaluate model quality. The results with two segments (latent groups) showed the best model quality ( $\mathrm{AIC}=1,270 ; \mathrm{BIC}=1,373 ; \mathrm{EN}=0.92)$. In segment 1 ("High hedonic technology seekers"; 57\%), hedonic evaluation of technological innovations has strong effects both on customer satisfaction $(\gamma=.60, p<.01)$ and shopping experience $(\gamma=.70, p<.01)$. In contrast, in segment 2 ("Low hedonic technology seekers"; 43\%), hedonic evaluation of technological

\footnotetext{
${ }^{2}$ Finite mixture partial least squares (FIMIX-PLS) segmentation is a method to uncover unobserved heterogeneity in the inner (structural) model. It captures heterogeneity by estimating the probabilities of segment memberships for each observation and simultaneously estimates the path coefficients for all segments.
} 
innovations has weaker, but significant effects on customer overall satisfaction $(\gamma=.22, p<.01)$ and shopping experience $(\gamma=.29, p<.01)$.

\section{CONCLUSION, DISCUSSION AND IMPLICATIONS}

\section{Discussion and theoretical implications}

With this research, we offer three main theoretical new contributions. First, the results show that hedonic evaluation of technology (including both pleasantness and interactivity) has positive and homogeneous effects across the value creation chain, for both consumers (increased satisfaction and better shopping experience) and retailers (higher store revisit intention). These results complement prior studies (Papagiannidis et al., 2017) that investigate part of the value chain especially the link between satisfaction and behavioral intentions (S. Chang et al., 2016; Maditinos \& Theodoris, 2010). Besides, this research specifically shows that the hedonic dimension of technological innovations has stronger effects on customer overall satisfaction and shopping experience than on store revisit intention. Thus, the hedonic dimension of technological innovations should become the main focus of interest. Specifically, our findings highlight the differences in the direct effects of pleasantness and interactivity: technology pleasantness affects directly store revisit intention while technology interactivity does not. This result might be related to the fact that interactivity is likely more important for affective and cognitive dimensions than for the conative one.

Second, this research brings further insights about the relationships between hedonic evaluations, customer satisfaction and store revisit intention. We specifically establish a significant mediation effect of customer overall satisfaction on the relationship between hedonic evaluation of technological innovations on store revisit intention. Thus, this result enriches the recent study of Inman and Nikolova (2017) who showed that satisfaction mediates the effect of retail technology on retail patronage intentions. Furthermore, our results highlight homogeneous indirect effects of technology pleasantness and interactivity on store revisit intention via the mediation of customer satisfaction. Thus, they provide a better understanding of the relationships between evaluation of technologies and 
customer satisfaction, and behavioral intentions (S. Chang et al., 2016; Maditinos \& Theodoridis, 2010; Papagiannidis et al., 2017).

Third, this research adds a new contribution by establishing the mediating effect of customer shopping experience on the relationship between hedonic evaluation of technological innovations on store revisit intention. Thus, if this research confirms the direct effects between evaluation of technological innovations and customer overall shopping experience (Demirkan \& Spohrer, 2014; Fiore et al., 2005) and between the latter and store revisit intention (Ettis, 2017; Koufaris, 2002; Lin et al., 2010; Triantafillidou \& Siomkos, 2014), to our knowledge it is the first to demonstrate the significant mediation effect of customer shopping experience on the relationship between hedonic evaluation of technological innovations and store revisit intention. This study reveals that shopping experience mediates positively the relationships between technology pleasantness or interactivity and store revisit intention. Therefore, this research enriches prior studies on the relationships between evaluation of technologies, shopping experience and behavioral intentions (Ettis, 2017; Koufaris, 2002; Lin et al., 2010).

\section{Practical and strategic implications}

Our offer specific guidance to retailers implementing technological innovations in their stores.

First, this research underlines the importance of hedonic evaluation of technological innovations which increases store revisit intention, and likely customer buying behavior in retail stores. However, retailers should pay attention to different aspects of customer hedonic evaluations. The results indicate that the technology pleasantness has a stronger effect on store revisit intention than technology interactivity. Therefore, if the main purpose of retail chains is to increase store traffic, they should emphasize the pleasantness. In contrast, if their objective is to increase satisfaction and shopping experience, both technology pleasantness and interactivity dimensions should be provided to customers. Second, the results show a significant mediation effect of customer overall satisfaction on the relationship between hedonic evaluation of technological innovations and customer revisit intention. Clearly, this result underlines the key role of satisfaction in store digitalization context. This research also shows that the effect of hedonic evaluation on customer satisfaction is stronger in 
magnitude than its effect on store revisit intention.. In accordance with this finding, retailers should focus on hedonic aspects of technologies to increase customer satisfaction. For instance, allowing customer participation to the store management process (through feedback) and the construction of the retail offer based on innovative technologies might give customers the feeling that they are importantThird, this study establishes a significant mediation role of customer overall shopping experience on the relationship between hedonic evaluation of technological innovations and store revisit intention. Thus, shopping experience has a central role in the relationship between these two variables. Interestingly, because the mediation effect of shopping experience is stronger than the other mediation effect identified, the findings suggest that retailers go further in providing a good experience based on innovative technologies. To date, most retailers build experience based on ambiance factors (music, colors, design, etc.). In the light of this research, a shift in this strategy by focusing on customer experience based on interaction with hedonic technologies is recommended. In order to improve customer experience based on the hedonic dimension of innovative technologies, it is important to invest in personnel and accompanying measures that enable a smooth use of technological innovations offered within stores (e.g. offering good wifi access, allowing customers give feedback on social networks, etc.).

\section{Limitations and further research}

Despite its theoretical and managerial contributions, this research has several limitations that suggest some research avenues. The sample should be enlarged and enriched to increase both external validity and the variety of different consumer profiles. A cross-cultural comparison also would be of interest, because retailers operate worldwide, and technological diffusion has been very quick, especially in emerging countries. Cultural differences might affect the role of technological innovations on value creation. As more channels get integrated into omnichannel retailing (Verhoef et al., 2015), do the number and nature of these different channels affect customers' evaluations of technological innovations in stores? Finally, the impact of the Internet of things on value creation needs to be investigated quickly; retailers are already investing massively in these technologies. 


\section{REFERENCES}

Beatson, A., Coote, L.V,. \& Rudd, J.M. (2006). Determining consume satisfaction and commitment through self-service technology and personal service usage. Journal of Marketing Management, 22(78), 853-882.

Bergkvist, L., \& Rossiter, J.R. (2007). The predictive validity of multiple-item versus single-item measures of the same constructs. Journal of Marketing Research, 44(2), 175-184.

Chang, H.H., Fu, C. S., Fang, P.W., \& Cheng, Y.C. (2016). The effects of relationship maintenance and relationship investment on self-service technology relationship performance. Information Technology \& People, 29(3), 496-526.

Chang, S. H., Chih, W. H., Liou, D. K., \& Yang, Y. T. (2016). The mediation of cognitive attitude for online shopping. Information Technology \& People, 29(3),618-646.

Cheung, G.W., \& Lau, R.S. (2008). Testing mediation and suppression effects of latent variables: Bootstrapping with structural equation models. Organizational Research Methods, 11(2), 296-325.

Chiesa, V., \&Frattini, F. (2011). Commercializing technological innovation: Learning from failures in high-tech markets. Journal of Product Innovation Management, 28(4), 437-454.

Choi, S.H., Yang, Y.X., Yang, B., \&Cheung, H.H. (2015). Item-level RFID for enhancement of customer shopping experience in apparel retail. Computers in Industry, 71(August), 10-23.

Collin-Lachaud, I., \& Vanheems, R. (2016). Navigating between real and virtual spaces: an exploration of the hybrid shopping experience. Recherche et Applications en Marketing, 31(2), 1-19. Davis, F. (1989). Perceived usefulness, perceived ease of use, and user acceptance of information technology. MIS Quarterly, 13(3), 319-340.

Demirkan, H., \& Spohrer, J. (2014). Developing a framework to improve virtual shopping in digital malls with intelligent self-service systems. Journal of Retailing and Consumer Services, 21(5), 860868.

Donovan, R.J., Rossiter, J.R., Marcoolyn, G., \& Nesdale, A. (1994). Store atmosphere and purchasing behavior. Journal of Retailing, 70, 283-294. 
Ettis, S.A. (2017). Examining the relationships between online store atmospheric color, flow experience and consumer behavior. Journal of Retailing and Consumer Services, 37(July), 43-55. Fiore, A.M., Kim, J., \& Lee, H.H. (2005). Effect of image interactivity technology on consumer responses toward the online retailer. Journal of Interactive Marketing, 19(3), 38-53. Fornell, C., \& Larcker, D.F. (1981). Evaluating structural equation models with unobservable variables and measurement error. Journal of Marketing Research, 18 (1), 39-50.

Grewal, D., Roggeveen, A.L., \& Nordfält, J. (2017). The Future of Retailing. Journal of Retailing, 93(1), 1-6.

Hair J.F., Black, W.C., Babin, B.J., \& Anderson, R.E. (2010). Multivariate data analysis, Upper Saddle River, NJ: Pearson Prentice.

Hausman, A., \& Siekpe, J., (2009). The effect of web interface features on consumer online purchase intentions. Journal of Business Research, 62(1),5-13.

Holbrook, M. B., \& Hirschman, E. C. (1982). The experiential aspects of consumption: Consumer fantasies, feelings, and fun. Journal of Consumer Research, 9(2), 132-140.

Hosany, S., \&Witham, M. (2010). Dimensions of cruisers' experiences, satisfaction, and intention to recommend. Journal of Travel Research, 49(3), 351-364.

Inman, J.J., \& Nikolova, H. (2017). Shopper-facing retail technology: A retailer adoption decision framework incorporating shopper attitudes and privacy concerns. Journal of Retailing, 93(1), 7-28. Jones, P., Clarke-Hill, C., Hillier, D., \& Comfort, D. (2005). The benefits, challenges and impacts of radio frequency identification technology (RFID) for retailers in the UK. Marketing Intelligence Planning, 23(4-5), 395-403.

Kim, J., \& Forsythe, S. (2008). Adoption of virtual try-on technology for online apparel shopping", Journal of Interactive Marketing, 22(2), 45-59.

Koufaris, M. (2002). Applying the technology acceptance model and flow theory to online consumer behavior. Information Systems Research, 13(2), 205-223.

Lanctôt, N., \& Hess, U. (2007). The timing of appraisals. Emotion, 7(1), 207-212.

Liao, Z., Shi, X., \& Wong, W.K. (2014). Key determinants of sustainable smartcard payment. Journal of Retailing and Consumer Services, 21(3), 306-313. 
Lin, C. Y., Fang, K., \& Tu, C. C. (2010). Predicting consumer repurchase intentions to shop online. Journal of Computers, 5(10), 1527-1533.

MacKinnon, D.P., Lockwood, C.M., \& Williams, J. (2004). Confidence limits for the indirect effect: Distribution of the product and resampling methods. Multivariate Behavioral Research, 39(1), 99-128. Maditinos, D.I., \& Theodoridis, K. (2010). Satisfaction determinants in the Greek online shopping context. Information Technology \& People, 23(4), 312-329.

Malhotra, N.K., Kim, S.S., \& Patil, A. (2006). Common method variance in IS research: A comparison of alternative approaches and a reanalysis of past research. Management Science, 52(12), 1865-1883.

Mancha, R., Leung, M.T. Clark, J., \& Sun, M. (2014). Finite Mixture Partial Least Squares for segmentation and behavioral characterization of auction bidders. Decision Support Systems, 57, 200211.

Martineau, P. (1958). The personality of the retail store. Harvard Business Review, 36(1), 47-55.

Meuter, M.L., Ostrom, A.L., Roundtree, R. I., \&Bitner, M.J. (2000). Self-service technologies: Understanding customer satisfaction with technology-based service encounters. Journal of Marketing, 64(3), 50-64.

Morris M.G., \& Venkatesh V. (2000). Age differences in technology adoption decisions implications for a changing work force. Personnel Psychology, 53, 375-403.

Nagy, M.S. (2002). Using a single-item approach to measure facet job satisfaction. Journal of Occupational and Organizational Psychology, 75(1), 77-86.

O’Cass, A., \& Carlson, J. (2012). An e-retailing assessment of perceived website-service innovativeness: implications for website quality evaluations, trust, loyalty and word of mouth. Australasian Marketing Journal, 20(1), 28-36.

Oh, L.B., Teo, H.H., \& Sambamurthy, V. (2012). The effects of retail channel integration through the use of information technologies on firm performance. Journal of Operational Management, 30(5), $368-381$. 
Pantano, E., \&Viassone, M. (2014). Demand pull and technology push perspective in technologybased innovations for the points of sale: The retailers' evaluation. Journal of Retailing and Consumer Services, 21(1), 43-47.

Papagiannidis S., Pantano E., See-To E., Dennis C., \& Bourlakis M. (2017). To immerse or not? Experimenting with two virtual retail environments. Information Technology \& People, 30(1), 163188.

Papagiannidis S., Pantano E., See-To E., \& Bourlakis M. (2013). Modelling the determinants of a simulated experience in a virtual retail store and users' product purchasing intentions. Journal of Marketing Management, 29(13-14), 1462-1492.

Piotrowicz, W., \& Cuthbertson, R. (2014). Introduction to the special issue information technology in retail: toward omnichannel retailing. International Journal of Electronic Commerce, 18 (4), 5-16. Podsakoff, P. M., MacKenzie, S. B., Lee, J.-Y, \& Podsakoff, N. P. (2003). Common methods biases in behavioral research: A critical review of the literature and recommended remedies. Journal of Applied Psychology, 88(5), 879-903.

Reinartz, W. W., Haenlein, M., \& Henseler, J. (2009) An empirical comparison of the efficacy of covariance-based and variance-based SEM", International Journal of Research in Marketing, 26(4), $332-344$.

Renko, S., \& Druzijanic, M. (2014) Perceived usefulness of innovative technology in retailing: Consumers' and retailers' point of view. Journal of Retailing and Consumer Services, 21(5), 836-843. Reynolds J., \& Sandström M. (2014). Digitalisation, retail transformation and change: what will European consumers want from their future shopping centre experience? Proceedings of the 4th Nordic Retail and Wholesale Conference Hosted by Center for Retailing, Stockholm School of Economics, Sweden. 5-6.

Rose, S., Clark, M., Samouel, P., \& Hair, N. (2012). Online customer experience in e-retailing: An empirical model of antecedents and outcomes. Journal of Retailing, 88(2), 308-322.

Spreng, R. A., MacKenzie, S. B., \& Olshavsky, R.W. (1996). A reexamination of the determinants of consumer satisfaction. Journal of Marketing, 60(3), 15-32. 
Steuer, J. (1992). Defining virtual reality: Dimensions determining telepresence. Journal of Communications, 42(4), 73-93.

Thorseng, A.A., \& Grisot, M. (2017). Digitalization as institutional work: A case of designing a tool for changing diabetes care. Information Technology \& People, 30(1), 227-243.

Triantafillidou, A., \& Siomkos, G. (2014). Consumption experience outcomes: satisfaction, nostalgia intensity, word-of-mouth communication and behavioural intentions. Journal of Consumer Marketing, $31(6 / 7), 526-540$.

Van Birgelen, M.V., De Jong, A., \& De Ruyter, K. (2006) Multi-channel service retailing: The effects of channel performance satisfaction on behavioural intentions. Journal of Retailing, 82(4), 367-377. Varadarajan, R., Srinivasan, R., Vadakkepatt, G. G., Yadav, M. S., Pavlou, P. A., Krishnamurthy, S., \& Krause, T. (2010). Interactive technologies and retailing strategy: A review, conceptual framework and future research directions. Journal of Interactive Marketing, 24(2), 96-110.

Vasudeva, S. \& Singh, G. (2017). Impact of E-Core Service Quality Dimensions on Perceived Value of M-Banking in Case of Three Socio-Economic Variables, International Journal of Technology and Human Interaction, 13(1), $20 \mathrm{p}$.

Venkatesh, V., Brown, S., Maruping, L., \& Bala, H. (2008). Predicting Different Conceptualizations of System Use: The Competing Roles of Behavioral Intention, Facilitating Conditions, and Behavioral Expectation. MIS Quarterly, 32(3), 483-502.

Venkatesh V., \& Morris, M.G. (2000). Why don't men ever stop to ask for directions? Gender, social influence, and their role in technology acceptance and usage behavior. MIS Quaterly, 24(1), 115-139. Verhoef, P.C., Kannan, P.K., \& Inman, J.J. (2015). From multi-channel to omni-channel: Introduction to the special issue on multi-channel retailing. Journal of Retailing, 91(2), 174-181.

Weijters, B., Rangarajan, D., Falk, T., \& Schillewaert, N. (2007). Determinants and outcomes of customers' use of self-service technology in a retail setting. Journal of Service Research, 10(1), 3-21. 


\section{APPENDIX 1. Measurement items}

\begin{tabular}{|c|c|c|}
\hline Main constructs & Attribute formulation & Sources/ references \\
\hline \multirow{2}{*}{$\begin{array}{l}\text { Hedonic evaluation } \\
\text { of technological } \\
\text { innovations }\end{array}$} & This technology is pleasant (Likert scale: 1 to 5) & $\begin{array}{l}\text { Derived from Lanctôt \& } \\
\text { Hess (2007) }\end{array}$ \\
\hline & This technology is interactive (Likert scale: 1 to 5 ) & $\begin{array}{l}\text { Derived from Fiore et al. } \\
(2005)\end{array}$ \\
\hline $\begin{array}{l}\text { Customer overall } \\
\text { satisfaction }\end{array}$ & $\begin{array}{l}\text { The use of this technology improves my overall } \\
\text { satisfaction toward the store (Likert scale: } 1 \text { to } 5 \text { ) }\end{array}$ & $\begin{array}{l}\text { Derived from Beatson et } \\
\text { al. (2006) }\end{array}$ \\
\hline $\begin{array}{l}\text { Customer overall } \\
\text { shopping } \\
\text { experience }\end{array}$ & $\begin{array}{l}\text { The use of this technology enriches my overall } \\
\text { shopping experience with the store (Likert scale: } 1 \\
\text { to } 5 \text { ) }\end{array}$ & $\begin{array}{l}\text { Derived from Choi et al. } \\
\text { (2015) }\end{array}$ \\
\hline $\begin{array}{l}\text { Store revisit } \\
\text { intention }\end{array}$ & $\begin{array}{l}\text { The use of this technology increases my intention } \\
\text { to revisit the store (Likert scale: } 1 \text { to } 5 \text { ) }\end{array}$ & $\begin{array}{l}\text { Derived from O'Cass \& } \\
\text { Carlson (2012) }\end{array}$ \\
\hline Control variables & Attribute formulation & Sources/ references \\
\hline Ease of use & $\begin{array}{l}\text { This technology is easy to use (Likert scale: } 1 \text { to } \\
\text { 5) }\end{array}$ & $\begin{array}{l}\text { Derived from Liao et al. } \\
\text { (2014) }\end{array}$ \\
\hline Frequency of use & $\begin{array}{l}\text { I use this technology frequently (Likert scale: } 1 \text { to } \\
\text { 5) }\end{array}$ & $\begin{array}{l}\text { Derived from Renko\& } \\
\text { Druzijanic (2014) }\end{array}$ \\
\hline
\end{tabular}

Note: All items used Likert scales with five points: $1=$ "Strongly disagree" and 5 = "Strongly agree" 


\section{FIGURES}

Figure 1. Research model

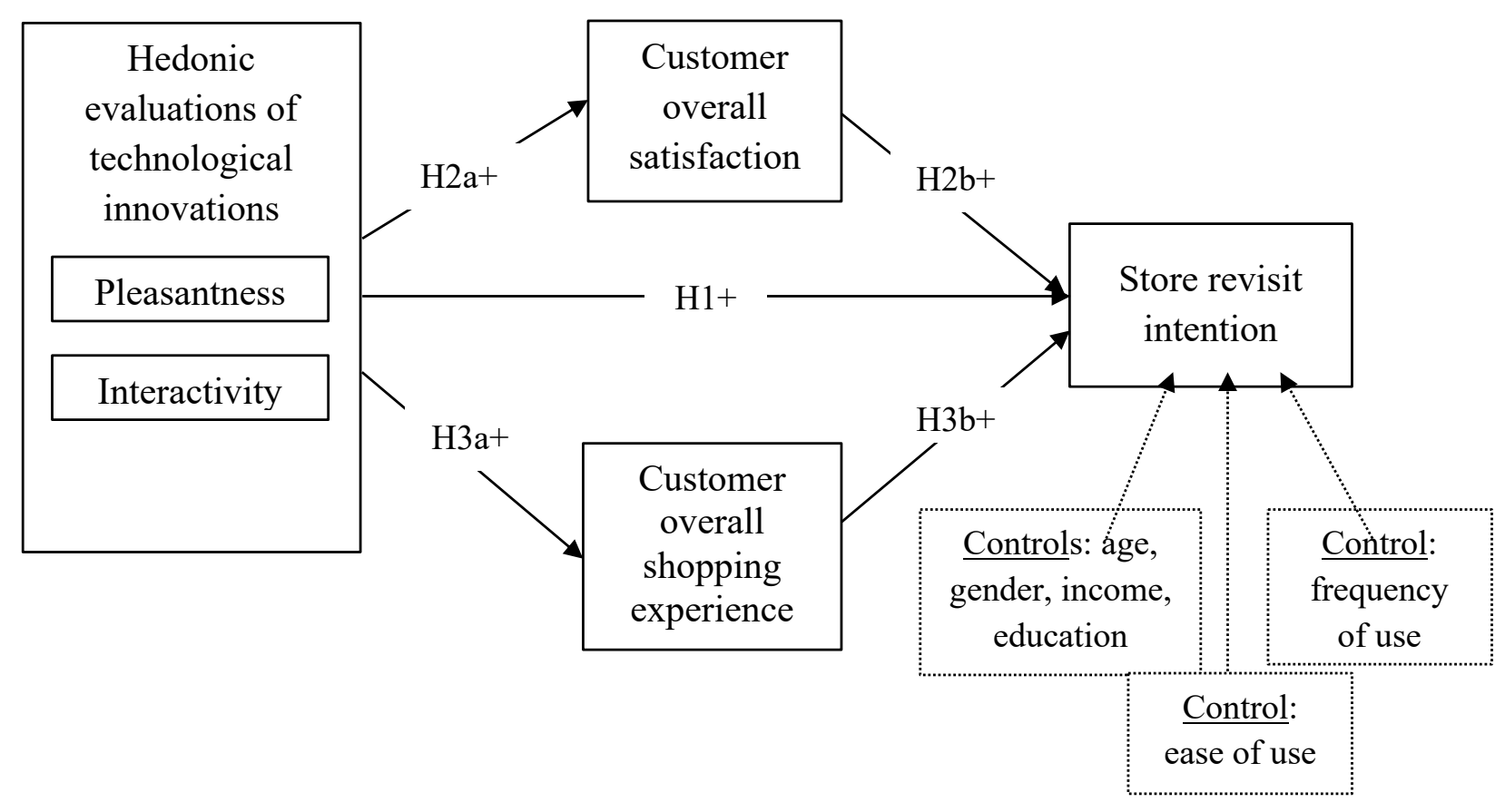




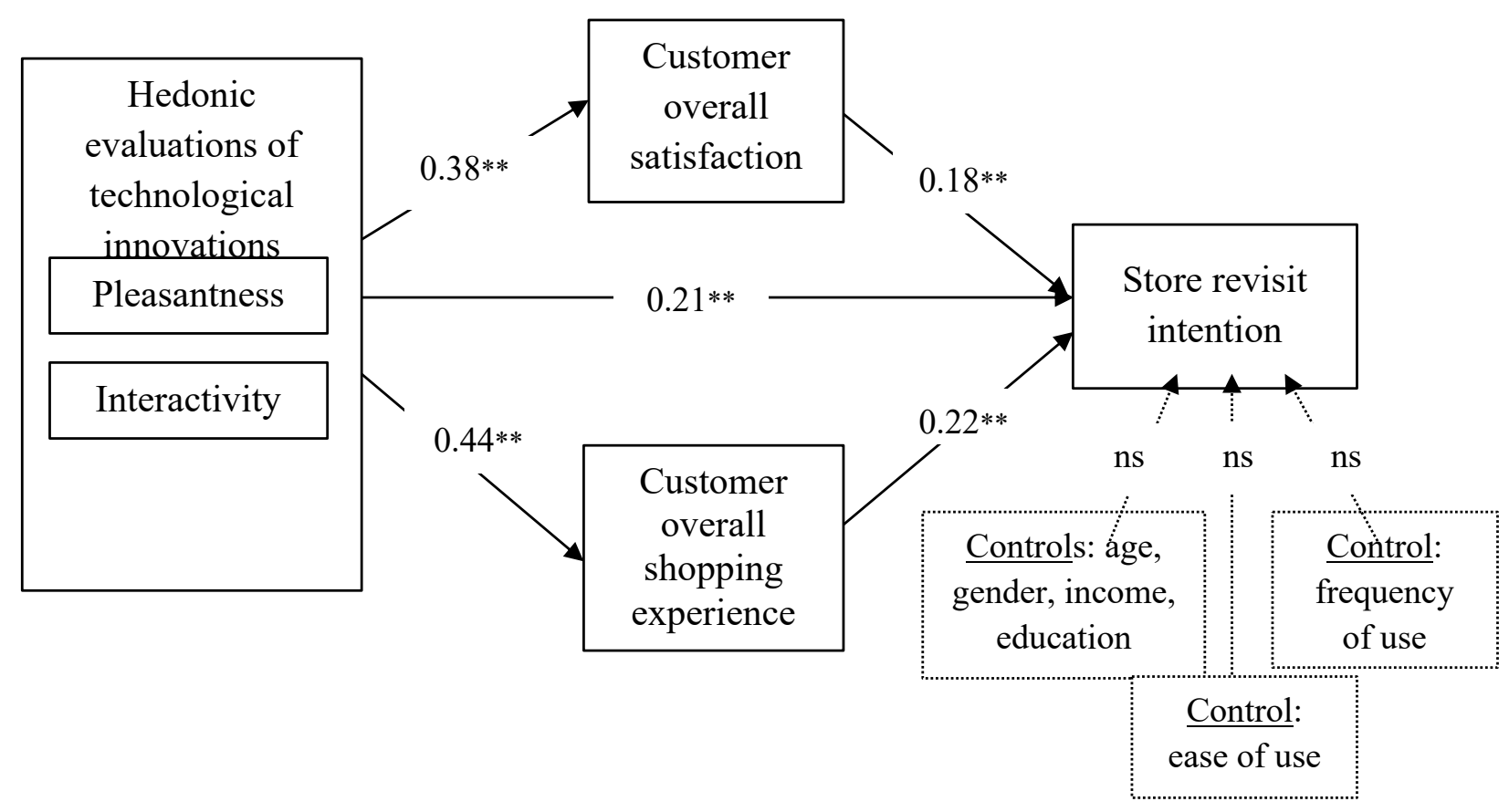




\section{TABLES}

Table 1. Measurement properties

\begin{tabular}{|c|c|c|c|c|}
\hline Constructs & Attributes/ items & $\begin{array}{l}\text { Standardized } \\
\text { coefficients }\end{array}$ & $\begin{array}{l}\text { Bootstrap t values } \\
\text { (1) }\end{array}$ & Reliability and validity \\
\hline \multirow{2}{*}{$\begin{array}{lr}1 . & \text { Hedonic } \\
\text { evaluations } & \text { of } \\
\text { technological } \\
\text { innovations }\end{array}$} & Pleasantness & $\lambda=.81$ & 39.17 & \multirow{2}{*}{$\begin{array}{l}\rho=.78 \\
\mathrm{AVE}=.64\end{array}$} \\
\hline & Interactivity & $\lambda=.79$ & 47.55 & \\
\hline $\begin{array}{l}\text { 2. Customer overall } \\
\text { satisfaction }\end{array}$ & Satis & $\lambda=1.00$ & --- & $\begin{array}{l}\rho=1.00 \\
\operatorname{AVE}=1.00\end{array}$ \\
\hline $\begin{array}{l}\text { 3. Customer overall } \\
\text { experience }\end{array}$ & Exp & $\lambda=1.00$ & --- & $\begin{array}{l}\rho=1.00 \\
\mathrm{AVE}=1.00\end{array}$ \\
\hline $\begin{array}{l}\text { 4. Store revisit } \\
\text { intention }\end{array}$ & Revisit & $\lambda=1.00$ & --- & $\begin{array}{l}\rho=1.00 \\
\mathrm{AVE}=1.00\end{array}$ \\
\hline 5. Frequency of use & Freq & $\lambda=1.00$ & --- & $\begin{array}{l}\rho=1.00 \\
\mathrm{AVE}=1.00\end{array}$ \\
\hline 6. Ease of use & Ease & $\lambda=1.00$ & --- & $\begin{array}{l}\rho=1.00 \\
\mathrm{AVE}=1.00\end{array}$ \\
\hline
\end{tabular}

Notes: ${ }^{(1)}$ Bootstrap values are not estimated when the construct is measured with a single item. 
Table 2. Descriptive statistics and discriminant validity check

\begin{tabular}{|c|c|c|c|c|c|c|c|c|c|}
\hline & $\begin{array}{c}\text { Means } \\
(\mathrm{SD})\end{array}$ & \multicolumn{8}{|c|}{ Correlations and AVE } \\
\hline & & 1 & 2 & 3 & 4 & 5 & 6 & 7 & 8 \\
\hline $\begin{array}{l}\text { 1. Hedonic } \\
\text { evaluation }\end{array}$ & $\begin{array}{c}2.95 \\
(0.76)\end{array}$ & $\begin{array}{r}\sqrt{0.78}= \\
0.88\end{array}$ & & & & & & & \\
\hline 2. Pleasantness & $\begin{array}{c}2.71 \\
(0.91)\end{array}$ & $.796^{* *}$ & $\sqrt{1}=1$ & & & & & & \\
\hline 3. Interactivity & $\begin{array}{c}3.18 \\
(0.97)\end{array}$ & $.820^{* *}$ & $.306^{* *}$ & $\sqrt{1}=1$ & & & & & \\
\hline $\begin{array}{l}\text { 4. Overall } \\
\text { satisfaction }\end{array}$ & $\begin{array}{c}3.29 \\
(0.92)\end{array}$ & $.389^{* *}$ & $.269^{* *}$ & $.357^{* *}$ & $1 \sqrt{1}=1$ & & & & \\
\hline $\begin{array}{l}5 . \quad \text { Overall } \\
\text { shopping } \\
\text { experience }\end{array}$ & $\begin{array}{c}2.93 \\
(1.00)\end{array}$ & $.441^{* *}$ & $.380^{* *}$ & $.334^{* *}$ & $.399^{* *}$ & $1 \sqrt{ } 1=1$ & & & \\
\hline $\begin{array}{l}\text { 6. Store revisit } \\
\text { intention }\end{array}$ & $\begin{array}{c}2.97 \\
(0.94)\end{array}$ & $.374^{* *}$ & $.350^{* *}$ & $.257^{* *}$ & $.334^{* *}$ & $.387^{* *}$ & $1 \sqrt{1}=1$ & & \\
\hline $\begin{array}{l}\text { 7. Frequency } \\
\text { of use }\end{array}$ & $\begin{array}{c}3.32 \\
(1.23)\end{array}$ & $.209^{* *}$ & $.140^{*}$ & $.196^{* *}$ & $.303^{* *}$ & $.197^{* *}$ & .112 & $\sqrt{1}=1$ & \\
\hline 8. Ease of use & $\begin{array}{c}3.89 \\
(1.00)\end{array}$ & $.166^{* *}$ & .016 & $.246^{* *}$ & $.175^{* *}$ & -.007 & .020 & $.212^{* *}$ & $\begin{array}{r}\sqrt{1}= \\
1\end{array}$ \\
\hline
\end{tabular}

Notes: $* p<0.05 ; * * p<0.01$. $\mathrm{SD}=$ standard deviation. For discriminant validity, the square root of the average variance extracted (AVE) values on the diagonal must be greater than the correlations between constructs, as was the case for all of the constructs. 
Table 3. Effects of pleasantness and interactivity on store revisit intention

\begin{tabular}{|c|c|c|}
\hline Relationships & Standardized coefficients & Results \\
\hline Direct effects & --- & --- \\
\hline Pleasantness $\rightarrow$ Store revisit intention & $\beta=0.20 * *$ & Confirmed \\
\hline Interactivity $\rightarrow$ Store revisit intention & $\beta=0.09 \mathrm{~ns}$ & Not confirmed \\
\hline Mediation effects & --- & --- \\
\hline $\begin{array}{l}\text { Pleasantness } \rightarrow \text { Overall satisfaction } \rightarrow \text { Store } \\
\text { revisit intention }\end{array}$ & $\begin{array}{c}\beta=0.05 * \\
{[0.24 \times 0.20]}\end{array}$ & Confirmed \\
\hline $\begin{array}{l}\text { Interactivity } \rightarrow \text { Overall satisfaction } \rightarrow \text { Store } \\
\text { revisit intention }\end{array}$ & $\begin{array}{l}\beta=0.07 * * \\
{[0.36 \times 0.20]}\end{array}$ & Confirmed \\
\hline $\begin{array}{l}\text { Pleasantness } \rightarrow \text { Overall shopping experience } \\
\rightarrow \text { Store revisit intention }\end{array}$ & $\begin{array}{l}\beta=0.08 * * \\
{[0.38 \times 0.22]}\end{array}$ & Confirmed \\
\hline $\begin{array}{l}\text { Interactivity } \rightarrow \text { Overall shopping experience } \\
\rightarrow \text { Store revisit intention }\end{array}$ & $\begin{array}{l}\beta=0.09 * * \\
{[0.33 \times 0.27]}\end{array}$ & Confirmed \\
\hline
\end{tabular}

Notes: $\mathrm{ns}=$ not significant $; * p<0.05 ; p<0.01$. 